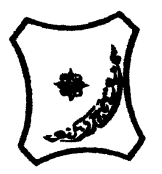

Bayero Journal of Pure and Applied Sciences, 8(2); 100 - 103

Received: April, 2015

Accepted: July, 2015

ISSN 2006 - 6996

\title{
EFFECT OF THERMAL AND PHYSICOCHEMICAL TREATMENT ON ABATTOIR WASTE WATER - A CASE STUDY OF IKPOBA-HILL ABATTOIR
}

\author{
Okuo, J.M. and * Moses, 0. \\ Department of Chemistry, Faculty of Physical Sciences \\ University of Benin, Benin City, Nigeria. \\ "E-mail: okponmwense.moses@uniben.edu, ${ }^{*} T e l e p h o n e:+2348055055189$
}

\begin{abstract}
Evacuation of abattoir waste waters into water bodies results in excessive proliferation of decomposers, thus causing oxygen depletion and eutrophication. This study is designed to find means of effectively treating the abattoir waste water before they are reused or discharged into water bodies. The waste water was taken from open drainage before it discharges into Ikpoba river water body and subjected to physicochemical and thermal treatment prior to adsorption by granulated activated charcoal (GAC). The waste water and treated water were analysed for chemical oxygen demand (COD), biochemical oxygen demand $\left(B O D_{5}\right)$, total nitrogen (TN), ammonium nitrogen, total phosphate (TP), total solid content (TSC), dissolved solid content (DSC), suspended solid and pH to ascertain the removal efficiency of the treatment procedure. The study revealed that the removal efficiency using a combination of adsorption, physicochemical and thermal treatment in treating waste water from an abattoir was most efficient for total phosphate $(95.78 \%)$ and least efficient for dissolved solid content (64.80\%).

Keywords: Heat, Coagulant, Adsorption, Treatment, Abattoir, Wastewater.
\end{abstract}

\section{INTRODUCTION}

Aquatic systems in many countries around the world are loaded with so much organic matters from abattoir waste waters resulting in excessive proliferation of decomposers. These organisms consume oxygen faster than it enters the water stream, thus resulting in oxygen depletion and eutrophication. The major environmental problems associated with abattoir wastewater are the large amount of suspended solids, liquid waste and odour generation (Gauri, 2006). It is noteworthy that most abattoirs in Edo state are sited close to rivers or drainages that empty into rivers, resulting in pollution of the surface water with organic materials, Adeyemo et al., (2009) observed that facilities for waste recovery, treatment, and reuse are either inadequate or nonexistent in most Nigerian abattoirs. This has resulted into a situation whereby wastes are indiscriminately and improperly discharged thus constituting environmental hazards (Coker et al. 2001; Muhirwa et al. 2010; Sharma, 2006; Osibajo and Adie, 2007). Handling and treatment of raw sewage such as abattoir waste water is supposed to involve three major steps, that is collection and removal of the sewage from the immediate human proximity; suitable treatment procedure and disposal or reuse of the treated sewage (Sharma, 2006). The practice in abattoir in most part of Nigeria including Ikpoba-Hill abattoir involves direct emptying of its sewage into rivers through drainages, without prior treatment and negating the accepted standard for the handling and treatment of raw sewage such as abattoir waste in Ikpoba-Hill abattoir.
The existing methods of purifying effluents are divided into the following: mechanical; physicochemical; biological and thermal treatment [10]. Because of the volume of discharges, size, dispersion and composition of the impurities, abattoir waste water, physicochemical and thermal methods was adopted in the research work for the treatment and recycling of waste water from an abattoir.

The motivation for this research work centre around the fact the fact that there are increasing population, industrialization and urbanization, as such, the quality and quantity of water required will also increase. The research work is therefore designed to find a way of effectively reducing pollution level of our surface water such as lakes, rivers and other water bodies. Moreso, it seeks to device a means of reusing the treated waste water - a process referred to as recycling.

\section{MATERIALS AND METHODS}

\section{Sample Collection}

The wastewater or effluent (raw wastewater samples) used in this research work was taken from Ikoba - Hill abattoir, a local abattoir plant located near Ikpoba Slope, Benin City in Ikpoba - Okha Local Government Area of Edo State. The wastewater samples were taken just after mixing with washing or processing water from the open drainage before entering into the water body. Normal abattoir operations are carried out from Monday to Saturday. The blood wash and the processing water from the abattoir are channeled directly into Ikpoba river. 
The abattoir waste water samples were collected in five different two-litre plastic containers, previously cleaned by washing with non - ionic detergent, rinsed with tap water and later soaked with $10 \% \mathrm{HNO}_{3}$ for 24 hours and finally rinsed with deionised water prior to usage in collection of the waste water.

During sampling, sample bottles were rinsed with sampled water three times and then filled to the brim. The waste water samples were collected everyday of the week in the first week and once in every week for five weeks the samples were labeled and transported to the laboratory where a composite sample was made and stored in the refrigerator at about $4^{\circ} \mathrm{C}$ prior to analysis. The $\mathrm{pH}$ of the waste water samples were measured in-situ. Samples were collected for six weeks. Twenty-five (25) litres of the composite waste water sample was Homogenised and thereafter filtered through a sand bed that has been washed and heated at $200^{\circ} \mathrm{C}$ for three hours, to kill the microorganism. The filtration was designed to remove the large settleable or suspended solids like bones, cartilages, tendons e.t.c. The filtrate was subjected to heat at $100^{\circ} \mathrm{C}$ for three hours; the cooled waste water was again filtered through another sand bed to remove the coagulated blood impurity in the waste water. The filtrate was allowed to sediment for 24 hours so as to further remove suspended solid from the liquid stream by gravitational settling.

Sedimentation alone is not sufficient to remove all suspended matters; coagulant was added to improve the coagulation of natural colloids in the waste water. To this end, $10 \mathrm{~g}$ of aluminum sulphate $\left(\mathrm{Al}_{2}\left(\mathrm{SO}_{4}\right)_{3} \cdot 18 \mathrm{H}_{2} \mathrm{O}\right)$ was added to the filtrate $(400 \mathrm{mg} / \mathrm{l})$. The mixture was agitated and allowed to sediment within 24 hours interval. The treated waste water was filtered through a sand bed. The slightly reddish colour of the filtrate resulting from dissolved organic matter which could not be precipitated by the chemical precipitant (alum) was ran through an adsorption bed packed into a column made of a granular activated charcoal, pre-heated sand and cotton wool. The granular activated charcoal served dual purpose of adsorbing and decolouring agent, thus helping to eliminate residual odour and colour in the treated waste water. This procedure resulted in clear colourless water. The waste water and treated water were analysed for chemical oxygen demand (COD), biological oxygen demand $\left(\mathrm{BOD}_{5}\right)$, Total nitrogen $(\mathrm{TN})$, Ammonical nitrogen, total phosphate (TP), total solid content (TSC), Dissolved solid content (DSC), suspended solid and $\mathrm{pH}$.

\section{RESULTS AND DISCUSSION}

Table 1: Analysis of Waste Water from Ikpoba-Hill Abattoir vi-a-vis the Physicochemically and the Thermally treated waste water.

\begin{tabular}{|c|c|c|c|c|}
\hline Parameters & $\begin{array}{l}\text { Waste Water } \\
\text { from Abattoir }\end{array}$ & $\begin{array}{l}\text { Thermal and } \\
\text { Coagulant } \\
\text { Treated Waste } \\
\text { Water }\end{array}$ & $\begin{array}{l}\text { Activated Charcoal treated } \\
\text { Water after Thermal and } \\
\text { Coagulation Treatment }\end{array}$ & $\begin{array}{l}\text { NESREA } \\
(1991) / \mathrm{WHO}(2006)\end{array}$ \\
\hline $\mathrm{pH}$ & 7.41 & 6.96 & 7.19 & $6.5-8.5$ \\
\hline $\mathrm{BOD}_{5}(\mathrm{mg} / \mathrm{l})$ & 166.25 & 136.67 & 57.95 & $20-40 \mathrm{mg} / \mathrm{l}$ \\
\hline $\operatorname{COD}(\mathrm{mg} / \mathrm{l})$ & 652.77 & 470.00 & 140.8 & $80-100 \mathrm{mg} / \mathrm{l}$ \\
\hline Total Nitrogen (mg/l) & 73.33 & 27.61 & 17.54 & No guideline \\
\hline Amonical Nitrogen $(\mathrm{mg} / \mathrm{l})$ & 38.11 & 16.00 & 5.60 & $50 \mathrm{mg} / \mathrm{l}$ \\
\hline Total Phosphate $(\mathrm{mg} / \mathrm{l})$ & 449.78 & 63.65 & 19.00 & $1-5 \mathrm{mg} / \mathrm{l}$ \\
\hline Total Solid Content (mg/l) & 5177.8 & 1733.33 & 933.33 & $500-1000 \mathrm{mg} / \mathrm{l}$ \\
\hline Dissolve Solid Content (mg/l) & 1704.51 & 1200.00 & 600.00 & $500-2000 \mathrm{mg} / \mathrm{l}$ \\
\hline Suspended Solid (mg/l) & 3473.29 & 533.33 & 333.33 & $20-30 \mathrm{mg} / \mathrm{l}$ \\
\hline
\end{tabular}

Table 2: Comparison of the effect of treatment patterns with waste water content.

\begin{tabular}{|c|c|c|c|c|c|}
\hline Parameters & $\begin{array}{l}\text { Waste } \\
\text { Water } \\
\text { from } \\
\text { Abattoir } \\
\text { (A) }\end{array}$ & $\begin{array}{l}\text { Thermal and } \\
\text { Coagulant } \\
\text { Treated Waste } \\
\text { Water } \\
\text { (B) }\end{array}$ & $\begin{array}{l}\text { Removal } \\
\text { Efficiency } \\
(\%) \text {. } \\
(A \text { and } B)\end{array}$ & $\begin{array}{l}\text { Activated Charcoal } \\
\text { treated Water after } \\
\text { Thermal } \\
\text { Coagulation } \\
\text { Treatment(C) }\end{array}$ & $\begin{array}{l}\text { Removal } \\
\text { Efficiency (\%) } \\
(A \text { and } C)\end{array}$ \\
\hline $\mathrm{pH}$ & 7.41 & 6.96 & N.A & 7.19 & N.A \\
\hline $\mathrm{BOD}_{5}(\mathrm{mg} / \mathrm{l})$ & 166.25 & 136.67 & 17.79 & 57.95 & 65.14 \\
\hline $\operatorname{COD}(\mathrm{mg} / \mathrm{l})$ & 652.77 & 470.00 & 28.00 & 140.8 & 78.43 \\
\hline Total Nitrogen $(\mathrm{mg} / \mathrm{l})$ & 73.33 & 27.61 & 62.35 & 17.54 & 76.08 \\
\hline Amonical Nitrogen $(\mathrm{mg} / \mathrm{l})$ & 38.11 & 16.00 & 58.02 & 5.60 & 85.31 \\
\hline Total Phosphate (mg/l) & 449.78 & 63.65 & 85.85 & 19.00 & 95.78 \\
\hline Total Solid Content (mg/l) & 5177.80 & 1733.33 & 65.75 & 933.33 & 81.97 \\
\hline Dissolve Solid Content (mg/l) & 1704.51 & 1200.00 & 29.60 & 600.00 & 64.80 \\
\hline Suspended Solid (mg/l) & 3473.29 & 533.33 & 84.64 & 333.33 & 90.40 \\
\hline
\end{tabular}


Bajopas Volume 8 Number 2 December, 2015

The $\mathrm{pH}$ value of the abattoir waste water was 7.41, this value dropped to 6.96 after applying heat and aluminum sulphate (alum) to the waste water, the decrease in $\mathrm{pH}$ level is as a result of hydrolysis of aluminium sulphate. The value of the $\mathrm{pH}$ rose from 6.96 to 7.19 after adsorption treatment of the waste water which has been treated with heat and alum thereby bringing the waste water to near neutral point due to adsorption of excess hydrogen ion.

The $\mathrm{BOD}_{5}$ of the waste water was $166.25 \mathrm{mg} / \mathrm{l}$, after treating the waste water with heat and aluminum sulphate, the $\mathrm{BOD}_{5}$ dropped to $136.67 \mathrm{mg} / \mathrm{l}$ amounting to $17.79 \%$ removal efficiency. This implies some of the biologically oxidisable organic matters were removed from the waste water by heat and alum sulphate (Ademorati, 1996). On passing the waste water which has been treated with alum and heat through the granular activated charcoal, the value of the $\mathrm{BOD}_{5}$, further reduced to $57.95 \mathrm{mg} / \mathrm{l}$, bringing about $65.14 \%$ removal efficiency when compared with the waste water from the abattoir. This indicated that the granular activated charcoal removed majority of the dissolved organic matters or compound which are biologically oxidisable.

The COD value of the waste water was $652.77 \mathrm{mg} / \mathrm{l}$. The COD value after treatment with heat and aluminium sulphate, reduced to $470.00 \mathrm{mg} / \mathrm{l}$, this indicated $28 \%$ removal efficiency in the COD value, and this implied that some amount of chemically oxidisable organic matter has been removed from the waste water by this treatment. On further treatment of the waste water by running it through granulated activated charcoal, the COD value of the water obtained was $140.80 \mathrm{mg} / \mathrm{l}$, amounting to $78.43 \%$ removal efficiency in the value of COD of the waste from the abattoir. This is an indication that the amount of dissolved organic substance in the waste water from an abattoir is high and the adsorption technique applied, has helped greatly in removing them from the waste water.

Total nitrogen, is an indication of the presence of organic matter in waste water (Van lier et al. 1998). Total nitrogen value in the waste water was $73.33 \mathrm{mg} / \mathrm{l}$. After treating the waste water with heat and aluminum sulphate, the value reduced to $27.61 \mathrm{mg} / \mathrm{l}$ amounting to $62.35 \%$ removal efficiency in the content of total nitrogen in the waste water from the abattoir. On passing the treated waste water through activated charcoal, the value of the total nitrogen dropped to $17.54 \mathrm{mg} / \mathrm{l}$ amounting to a removal efficiency of $78.08 \%$ reduction, thus improving the quality of the waste water from an abattoir.

The ammonical nitrogen, is an indication of the freshness of waste water and the presence of organic matter in waste water (Sharma, 2006). The ammonical nitrogen value in the waste water was $38.11 \mathrm{mg} / \mathrm{l}$. After treating the waste water with heat and aluminum sulphate, the value reduced to $16.00 \mathrm{mg} / \mathrm{l}$ amounting to $58.02 \%$ removal efficiency in the content of ammonical nitrogen in the waste water from the abattoir. On passing the treated waste water through activated charcoal, the value of the ammonical nitrogen dropped to $5.60 \mathrm{mg} / \mathrm{l}$ amounting to a reduction of $85.31 \%$ reduction, thus improving the quality of the waste water by drastically reducing the value of the ammonical nitrogen in the waste water from an abattoir.

The value of the phosphorous in the form of phosphate was $449.78 \mathrm{mg} / \mathrm{l}$ in the waste water from the abattoir. The use of heat and aluminum sulphate removed phosphorous from the waste water to a value of $63.65 \mathrm{mg} / \mathrm{l}$, amounting to $85.85 \%$ removal efficiency in phosphate concentration in waste water from an abattoir.
$\mathrm{Al}^{3+}(\mathrm{aq})$
$\mathrm{AlPO}_{4}(\mathrm{aq})$

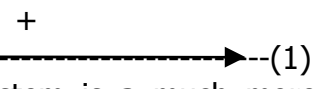
$\mathrm{PO}_{4}^{3-}(\mathrm{aq})$

What occurs in the system is a much more complex process. A possible reaction involves the displacement of $\mathrm{OH}^{-}$ions by partially protonated phosphate species. $\mathrm{Al}(\mathrm{OH})_{3}+\mathrm{HPO}_{4}{ }^{2-}(\mathrm{aq})+\mathrm{H}_{2} \mathrm{O}$

$\mathrm{AlOH}\left(\mathrm{HPO}_{4}\right) \cdot \mathrm{H}_{2} \mathrm{O}(\mathrm{s})+2 \mathrm{OH}^{-}(\mathrm{aq})$----------(2)

On treating the water therefrom, by passing it through granular activated charcoal, the value of the phosphate reduced to $19.00 \mathrm{mg} / \mathrm{l}$ amounting to $98.78 \%$ removal efficiency. This process has to a great extent removed phosphate either in organic or inorganic form from the waste water therefore making it safe either for reuse or discharge into water body and hence reduces the risk of eutrophication.

Total solid content, which is made up of the dissolved solid and suspended solid has a value of $5177.80 \mathrm{mg} / \mathrm{l}$, this value reduced to $1733.33 \mathrm{mg} / \mathrm{l}$ after treating the waste water from the abattoir with heat and aluminum sulphate. This value obtained amounted to $65.75 \%$ removal efficiency in total solid content. When the water obtained was passed through granular activated charcoal, the value the value of the total solid content further reduced to $933.33 \mathrm{mg} / \mathrm{l}$, amounting to $81.97 \%$ removal efficiency. This wass below the permissible level of $1000 \mathrm{mg} / \mathrm{l}$ set by WHO (2006). Total solid content, affects the palatability of water and corrosion of container (Kruawal et al. 2005).

The value of the suspended solid which is a measure of the turbidity, was $3473.29 \mathrm{mg} / \mathrm{l}$. After treating with heat and aluminum sulphate, the value reduced to $533.33 \mathrm{mg} / \mathrm{l}$ amounting to $84.64 \%$ removal efficiency. The water obtained was further treated with granulated activated charcoal and the value of the suspended solid reduced to $333.33 \mathrm{mg} / \mathrm{l}$ amounting to $90.40 \%$ removal efficiency compared with the fresh waste water from the abattoir.

The value of the dissolved solid which is an indication of the dissolved organic and/or inorganic substances in the waste water was $1704.51 \mathrm{mg} / \mathrm{l}$ and after treating the waste water from the abattoir with heat and aluminum sulphate, the value reduced to 1200.00 amounting to $29.60 \%$ removal efficiency, indicating that the heat and aluminum sulphate did not have a significant effect on the quantity of dissolved organic and/or inorganic substances In the waste water. On further treatment of the water obtained, with granulated activated charcoal, the value of the dissolved solid reduced to $600.00 \mathrm{mg} / \mathrm{l}$ amounting to $64.80 \%$ removal efficiency, thus showing an improvement in the removal of the dissolved solid content whether organic or inorganic in origin. 


\section{CONCLUSION}

The removal efficiency obtained with the use of a combination of a physicochemical and thermal treatment for waste water from an abattoir was high for total phosphate $(95.78 \%)$; suspended solid $(90.40 \%)$; ammonical nitrogen (85.31\%); total solid content $(81.79 \%)$; COD $(78.43 \%)$; total nitrogen $(76.08 \%)$. The removal efficiency for $\mathrm{BOD}_{5}$ and dissolved solid content were $65.14 \%$ and $64.80 \%$ respectively. The implication of the above outcome is that the treated waste water from the abattoir had an increase in the amount of oxygen available in the water as well as a high reduction in the factors responsible for the formation of eutrophication due to heavy presence of phosphates and nitrates.

The odour and colour associated with the waste water were also drastically reduced with the use of the combination therapy. This combination therapy can be use in our local abattoir to effectively reduce the

\section{REFERENCES}

Adeyemo O., Adeyemi I., Awosanya E.,: "Cattle cruelty and risks of meat contamination at Akinyele cattle market and slaughter slab in Oyo State, Nigeria". Tropical Animal Health and Production, 41, 1715- 1721. (2009.)

Ademoriti C.M.A: Environmental Chemistry and Toxicology. Foludex Press Ltd.. Ibadan. 96, $\left(1996^{1}\right)$.

Coker, A.O., Olugasa, B.O., and Adeyemi, A.O.,: "Abattoir Wastewater Quality in South Western Nigeria". Proceedings of the 27th WEDC Conference. Lusaca, Zambia. 329-331. (2001)

Gauri S.M.,: Treatment of wastewater from abattoirs before land application: a review. Bioresource Technology97, 1119-1135. (2006.)

Kruawal K., Sacher F., Werner A., Miller J., Knepper T.P.,: Chemical water quality in Thailand and its impacts on the drinking water production in Thailand. Science of the Total Environment340, 57-70. (2005)

Muhirwa D., Nhapi I., Wali U., Banadda N., Kashaigili J., Kimwaga R.. Characterization of wastewater from an abattoir in Rwanda and the impact on downstream water quality. International Journal of Ecology \& Development 16, 30-46. (2010) menace of odour, eutrophication and deoxygenation of our water bodies to a bearable level.

\section{RECOMMENDATIONS}

This method of treating abattoir waste water is recommendable for large, medium and small scale abattoir factories as it will go a long way at ameliorating the problems of discharging untreated abattoir waste water into our water bodies. Moreso, it will be academically and scientifically beneficial to the abattoir industries and our water environment for microbial analysis of the abattoir factory waste water to be carried out in the future with particular attention on it effect on our water bodies, its consumption and designing of microbial waste treatment method for abattoir waste water prior to discharging it into our water bodies.

Nafarmda, W.D., Yayi, A., and Kubkomawa, H.I.,: "Impact of Abattoir Waste on Aquatic Life: A Case Study of Yola Abattoir". Global. J. Pure. Appli. Sci. 12(1):31-33. (2006)

National Environmental Standards And Regulation Enforcement Agency, NESREA, (formerly FEPA),: Guidelines And Standards for Environmental Control In Nigeria. Abuja. (1991).

Osibajo, O., and Adie, G.U.,: "Impact of Effluent from Bodija Abattoir on the Physico- Chemical Parameters of Osinkaye Stream in Ibadan City, Nigeria". Afri. J. Biotech. 6(15):1806- 1811. (2007)

Sharma B.K.,: "Sewage and Sewage Treatment": Industrial Chemistry (Including Chemical Engineering). Goel Publishing House. 15 Ed. Delhi. Pg 133-150 (2006).

van Lier, Pol, Seeman, and Lettinga.,: Decentralized Urban Sanitation Concepts: Perspectives for Reduced Water Consumption and Wastewater Reclamation for Reuse. EP\&RC Foundation, Wageningen (The Netherlands), SubDepartment of Environmental Technology, Agricultural University, (1998).

World Health Organization, (WHO): Guidelines for Drinking water Quality. $3^{\text {rd }}$ ed. Vol.(1) Recommendation. WHO, Geneva, Switzerland. 515, (2006). 